Agro-Science Journal of Tropical Agriculture, Food, Environment and Extension Volume 17 Number 2 (Mav 2018) pp. $27-36$

ISSN 1119-7455

\title{
REACTIONS OF COMMERCIAL CULTIVARS OF OKRA, PEPPER, AND TOMATO TO CUCUMBER MOSAIC VIRUS DISEASE
}

\author{
Salaudeen, M.T., Oluwatosin, O. and Gana, A.S. \\ Department of Crop Production, School of Agriculture and Agricultural Technology, Federal \\ University of Technology, P. M. B. 65, Minna, Niger State, Nigeria \\ Corresponding author's email: mtsalaudeen@ futminna.edu.ng
}

\begin{abstract}
Okra (Abelmoschus esculentus), pepper (Capsicum spp.) and tomato (Solanum lycopersicum) are rich sources of minerals and vitamins required by humans for normal growth and development. However, the productivity of these vegetables is seriously constrained by Cucumber mosaic virus (CMV) disease. To date, adoption of resistant cultivars is the most effective, ecologically sound and sustainable management strategy against the disease. Therefore, selected cultivars of okra (Clemson Spineless, Ex Bassawa -2 and NHAe 47 - 4), pepper (California Wonder, Cayenne and Yolo Wonder) and tomato (Roma Savanna, Tropimech, and UC82B) were evaluated for resistance to CMV. The experiment was conducted under screenhouse and field conditions in Minna, Southern Guinea Savanna zone of Nigeria. Completely randomised design with six replications was used in screenhouse while the field trial was laid out using randomised complete block design with three replications. Seedlings were inoculated with CMV at 10 days after emergence. Disease incidence, disease severity, growth and yield characteristics were recorded. Data were subjected to analysis of variance at $p \leq 0.05$. Infected plants elicited mosaic symptoms but disease severity was cultivar dependent. Plant height, leaf area, fruit length, fruit diameter and fruit weight were all reduced by $C M V$. The lowest disease incidence $(<35 \%)$, severity $(<3)$, reductions in morphological and yield parameters ( $<10 \%$ ) were found in Ex-Bassawa-2, Cayenne, and Roma Savanna. This indicated that they contained CMV tolerant genes. Therefore, the three most tolerant cultivars (Ex-Bassawa-2 cultivar of okra, Cayenne of pepper and Roma Savanna of tomato) are recommended to farmers in CMV prone areas.
\end{abstract}

Keywords: CMV; Disease incidence; Growth and yield; Severity; Vegetables

\section{INTRODUCTION}

Vegetables have been recognized as important components of human nutrition particularly in sub-Saharan Africa (SSA) where there is a serious problem of malnutrition (Abro and Sadaqat, 2010). These crop species are not only good sources of essential vitamins and minerals (Bakhru, 2003), they are widely used as the complement to starchy staple foods. In Africa, vegetables constitute the fourth largest group of commodities produced for various uses. Okra (Abelmoschus esculentus L. Moench) also known as lady's finger is a member of the family Malvaceae (Walker, 2012). It is cultivated in several parts of tropical and sub-tropical Africa (Saifullah and Rabbani, 2009). Okra is grown on subsistence and large-scale farms in Iran, Turkey, West Africa, many Asian countries and the southern United States. In 2016, the world total okra output was approximately 8.9 million tonnes.
India was the largest producer with about 5.5 million tonnes, followed by Nigeria which produced approximately 2 million tonnes and Sudan had about 287, 300 tonnes (FAO, 2016). Pepper (Capsicum spp.), a vegetable of global importance is believed to have originated in Central and South America. Its cultivation later spread to the New World such as Thailand, Indonesia, India, Malaysia and Philippines in Asia; and Nigeria, Ghana, Senegal, and Kenya in Africa in 1943 (Rehima, 2006). It is a dependable source of income for smallholder farmers in developing countries such as Bhutan, Cambodia, China, Ethiopia, Ghana, India, Indonesia, Nigeria, Pakistan and Thailand (Lin et al., 2013). Today, hot pepper (chili) is an important commodity in world spice trade and the popularity of sweet pepper has continued to rise in the tropics. Peppers can be consumed in 
fresh, dried or processed form (Idowu-Agida et al., 2010). In 2016, the world production of peppers was estimated at 546.3 million tonnes. Nigeria was the largest producer in Africa with about 67, 000 tonnes (FAO, 2016). Tomato (Solanum lycopersicum) is an herbaceous fruiting plant (Babalola et al., 2010). Though believed to have originated in Latin America, it has been identified as one of the most widely grown vegetables with the ability to survive in diverse environmental conditions (Rice et al., 1987). Tomato fruit is rich in vitamins and minerals that are essential in the human diet. It may be eaten fresh as salad or processed into purees or pastes which are basically used for stews and soups as well as fruit drinks (Babalola et al., 2010). The world tomato production in 2016 stood at 177 million tonnes (FAO, 2016). In Africa, Egypt with about 7.9 million tonnes was the largest producer, followed by Nigeria which produced approximately 2.2 million tonnes.

In spite of the numerous uses of okra, pepper, and tomato, their productivity is adversely constrained by insect pests and diseases (Feldmann et al., 2009). Vegetable crops are attacked by several pathogens including Cucumber mosaic virus (CMV). Cucumber mosaic virus is pathogenic on over 1000 plant species in different genera and families (Palukaitis and Garcia-Arenal, 2003). Epidemiological studies have revealed that the virus is seed-borne (O'keefe et al., 2007) and long distance dissemination is facilitated by over 75 species of aphids in a non-persistent manner. Although insecticides may be applied to control the aphid vectors of the virus (Hartz and Cantwell, 2008), cultivation of resistant genotypes is the most effective and sustainable approach (Salaudeen, 2016). Adoption of virus-resistant varieties is cheap, effective, easy to adopt, environment-friendly and sustainable. A lot of vegetables, particularly okra, pepper, and tomato are grown in Minna, Southern Guinea Savanna agro-ecology of Nigeria. However, there is a scarcity of information on their level of resistance to CMV disease. It was therefore important to assess the resistance status of some of the most common cultivars of these vegetables in case of sudden CMV disease outbreak. This information would be useful for developing preventive measures against poor yield and total crop loss. Therefore, this research was conducted to determine the level of resistance in the selected vegetable cultivars to Cucumber mosaic virus disease.

\section{MATERIALS AND METHODS}

Virus source and maintenance

An isolate of CMV obtained from the stock in the Department of Crop Production, Federal University of Technology, Minna, Nigeria was used for inoculation. The isolate was maintained at room temperature over silica gels in vial bottle. The CMV inoculum was multiplied in the plants of a susceptible cowpea cultivar, Ife Brown. This was accomplished by grinding the CMV- infected leaves in extraction buffer, $\mathrm{pH} 7.2(0.1 \mathrm{M}$ sodium phosphate dibasic, $0.1 \mathrm{M}$ potassium phosphate monobasic, $0.01 \mathrm{M}$ ethylene diamine tetra acetic acid and $0.001 \mathrm{M}$ L-cysteine per litre of distilled water) at the ratio of $1: 1 \mathrm{w} / \mathrm{v}(1$ $\mathrm{g}$ leaf in $1 \mathrm{~mL}$ inoculation buffer). Just before inoculation, the upper leaf surface was dusted with carborundum powder (600-mesh) (Fisher Scientific, Fair Lawn, NJ). A piece of cheesecloth was dipped in the virus extract and then rubbed on the dusted leaf surface. At three weeks after inoculation symptomatic leaves were harvested from infected plants and subjected to Enzyme-Linked Immunosorbent Assay (ELISA), using CMV polyclonal antibody (Kumar, 2009). The ELISA positive leaf tissues were preserved on anhydrous calcium chloride $(\mathrm{CaCl} 2)$ in plastic vials by placing $10 \mathrm{~g}$ of the salt in the vial covered with a thin layer of nonabsorbent cotton wool and 1 $\mathrm{g}$ of the virus-infected leaf was folded into the vial and covered. The vials were maintained at room temperature $(37 \mathrm{oC})$.

\section{Source of seeds}

The three most popular okra (Clemson Spineless, Ex-Basawa-2 and NHAe47-4), pepper (California Wonder, Cayenne and Yolo Wonder), and tomato (Roma Savanna, Tropimech and UC82B) cultivars in the study area were evaluated. Seeds of Ex-Basawa-2 and NHAe 47-4 were respectively sourced from the Institute for Agricultural Research (IAR), Samaru, Ahmadu Bello University, Zaria, Kaduna State, Nigeria and from the stock in the Department of Crop Production, Federal University of Technology, Minna. Clemson Spineless okra, pepper and tomato seeds were purchased from an Agrochemical store in Minna. These cultivars were selected because they are the most popular vegetables in the study area. 


\section{Screenhouse Study \\ Crop establishment and inoculation}

The screenhouse experiment was conducted under screenhouse conditions at the Teaching and Research Farm, Federal University of Technology, Minna, Niger State during the 2014 cropping season. It was carried out using three independent trials. The three cultivars of each crop constituted the treatments. Treatments were arranged as Completely Randomized Design (CRD) with six replications. This arrangement was made for both inoculated and uninoculated (control) treatments of each cultivar. Seeds of the selected okra, pepper and tomato cultivars were sown in plastic pots $(30 \mathrm{~cm}$ diameter and $30 \mathrm{~cm}$ high). The pots were perforated at the bottom and then a thin layer of small stones was placed in them, followed by a thin layer of dry grass to ensure good drainage. The pots were then filled with heat-sterilized topsoil (3.8 kg per pot) and placed on iron benches ( 8 $\mathrm{m} \times 12 \mathrm{~m})$ in a screenhouse. Grooves not more than $1.5 \mathrm{~cm}$ deep and $7.5 \mathrm{~cm}$ apart were made and the okra seeds were dispensed into them. The tomato and pepper seeds were sown in drills and firmed with soil. The soil was then sprinkled with water from a watering can. At 10 days after emergence, seedlings were thinned to one plant per stand, maintaining five plants per pot. All seedlings for virus trial were inoculated with CMV extract at 10 days after emergence. At the time of inoculation, CMV inoculum was recovered from the dehydrated leaf tissues by grinding in extraction buffer, $\mathrm{pH}$ 7.2. The procedure for inoculation was as described above. Uninoculated plants of each cultivar were kept in a separate screenhouse to serve as the control.

\section{Field Study \\ Experimental site}

Field evaluation was conducted at the Teaching and Research Farm of the Federal University of Technology, Minna, Niger State, Nigeria, during the 2014 cropping season. The site used for the experiment has been under the cultivation of arable crops (maize, cowpea and yam) in the last five years. The bearing and elevation of the site (90 51'N, 6044 'E; $212 \mathrm{~m}$ above sea level) were captured using the Geographical Positioning System (GPS, Garmin, Taiwan) equipment.

Crop establishment, management and inoculation

The site with a field size of $649 \mathrm{~m} 2$ was cleared of the existing trash. The field was sprayed with a systemic herbicide (glyphosate) at the rate of 3 litres ha-1 on 13th July 2014. This was followed by ridging on 28th July 2014. Seeds of the three vegetable cultivars were sown on 31st July 2014. They were sown directly on ridges at a spacing of $75 \mathrm{~cm}$ (interrow) and $50 \mathrm{~cm}$ (intra-row). Mulching was done using dry grass to prevent raindrop splashes, conserve soil moisture and also to prevent birds from picking out already sown seeds. Seedlings were thinned to one plant per stand at 1 week after emergence. Seedlings were inoculated with CMV extract at 10 days after emergence, using the same procedure described for the screenhouse evaluation. Both inoculated and uninoculated plants were sprayed with insecticide (Cypermethrin $10 \%$ E.C.) at the rate of 0.5 litre ha-1 at 2-week interval. The first weeding was done manually with a hoe at 14 days after planting. Subsequent weedings were carried out manually at two and four weeks intervals. Fruits were harvested manually with pruning scissors for okra and with hands for pepper and tomato using hand gloves. This was carried out at an interval of four days when the vegetables were fully matured, that is when the tip of okra fruits were observed to break easily when snapped with fingertips and as the pepper and tomato fruits turned red.

\section{Treatments and experimental design}

Treatments consisted of three cultivars of okra (Clemson Spineless, Ex Bassawa -2 and NHAe 47-4), pepper (California Wonder, Cayenne and Yolo Wonder) and tomato (Roma Savanna, Tropimech and UC82B). Three independent trials were laid out for okra, pepper and tomato cultivars in a Randomized Complete Block Design (RCBD) with three replications. Each treatment was evaluated in four ridges (each $5 \mathrm{~m}$ long) with $0.75 \mathrm{~m}$ interrow spacing for both inoculated and uninoculated (control) plots.

\section{Data collection and statistical analysis}

The plants were assessed for disease incidence, disease severity, morphological and yield characters. Disease incidence was taken as a percentage of the inoculated plants exhibiting symptoms of infection at 1 and 2 weeks after inoculation (WAI). Disease severity was recorded as symptom severity scores (SSS), using 1 - 5 visual scale (Arif and Hassan, 2002). On the scale, 1 - no symptoms (apparently healthy plant); 2 - slightly mosaic leaves (10-30\%); 3 - mosaic (31-50\%) and leaf distortion; 4 - severe mosaic (51-70\%), leaf distortion and stunting; 5 - severe mosaic $(>70 \%)$, stunting and death of plants. Percentage reduction/loss (\%) was calculated 
for each of the growth and yield parameters (plant height, leaf area, fruit length, fruit diameter and fruit weight) using the formula:

Reduction/loss $(\%)=\left[\frac{\mathrm{Xu}-\mathrm{Xi}}{\mathrm{Xu}}\right] \times 100$ (Sarra, 2005)

where:

$\mathrm{Xu}$ - Mean of uninoculated plants

$\mathrm{Xi}$ - Mean of inoculated plants

Data were subjected to Analysis of Variance using the PROC GLM of SAS (Statistical Analysis System, 2008). Where $F$ test was significant, means were separated using the Least Significant Difference (LSD).

\section{RESULTS}

Cucumber mosaic virus disease incidence

The data on CMV disease incidence from the evaluated vegetables are presented in Table 1. In both screenhouse and field trials, symptoms of CMV infection were first observed at five days after inoculation (DAI) for pepper and 6 DAI for okra and tomato, except for Cayenne, Ex-Bassawa-2 and Roma Savanna in which first symptoms were observed at 7 DAI, 10 DAI and 14 DAI, respectively. Symptoms observed included leaf discolouration, followed by mosaic on leaves and stunted growth on infected Clemson Spineless and NHAe 47-4 cultivars of okra. On pepper cultivars, symptoms observed were leaf discolouration followed by mild mottling of leaves to severe mosaic on leaves and stunted growth, particularly in Yolo Wonder. Chlorosis, severe mosaic and stunted growth were also observed in infected plants of California Wonder. Conversely, Cayenne plants elicited very mild leaf mottling. Symptoms observed in infected tomato plants included chlorosis of the older leaves, blistering and stunted growth. At 1 WAI, there were no symptoms on Roma Savanna but at 2 WAI, mild mosaic symptom was observed. There was no apparent symptom of infection on the leaves of uninoculated (control) plants.

Disease incidence differed significantly $(p<0.05)$ among the crop cultivars. At $1 \mathrm{WAI}$, the highest disease incidence was observed in infected plants of Yolo Wonder $(82.5 \%)$ while the inoculated plants of Roma Savanna did not exhibit disease symptom. Among the okra cultivars, disease incidence was significantly highest in infected plants of NHAe47-4 (37.5 $\%)$, followed by Clemson Spineless $(28.3 \%)$ while the lowest was found in Ex-Bassawa-2 $(10 \%)$. In pepper, the diseased plants of Yolo Wonder suffered the highest incidence of infection $(82.5 \%)$ while Cayenne exhibited the lowest level of infection (20\%). In tomato, the highest disease incidence was observed in UC82B (30.8\%), followed by Tropimech (25 $\%)$ while the inoculated plants of Roma Savanna were apparently symptomless. At 2 WAI, although the incidence of CMV infection was highest in NHAe47-4 (95.8\%), the value observed was not significantly different from that in Clemson Spineless (90.8 $\%)$. In the field trial, disease incidence was still significantly lower in Clemson Spineless than NHAe47-4. Conversely, disease incidence was mildest in infected plants of Ex-Bassawa-2 at 1 WAI $(16.7 \%)$ and 2 WAI (22\%). Among the pepper cultivars, disease incidence at $2 \mathrm{WAI}$ took the same trend as observed at $1 \mathrm{WAI}$ (28.3-100\%) but higher values were obtained at 2 WAI (31.3-100\%). In tomato plants, the trend of infection at 1 WAI $(0-30.6 \%)$ was similar to that observed at 2 WAI (18.1 -81.7 $\%)$.

\section{Cucumber mosaic virus disease severity}

The severity of CMV infection varied significantly among crop cultivars as shown in Table 2. In both screen house and field trials, symptom expression was generally low at 2 WAI except in Yolo Wonder and California Wonder which showed intermediate to high level of infection. Among the okra cultivars, disease severity was consistently highest in NHAe 47-4 (score - 2.8- 4.1), followed by Clemson Spineless (score - 2.4-3.9), while ExBassawa-2 (score - 1.1- 1.9) consistently elicited the lowest symptom severity. For pepper, the lowest disease severity was observed in inoculated plants of Cayenne (score - 1.5- 2.9) throughout the period of evaluation. A similar trend was observed among the tomato cultivars in which Roma Savanna (score - 1.1- 1.7) consistently expressed the lowest disease severity symptoms. Although disease severity was consistently highest in infected plants of UC82B (score - 1.8- 3.4), symptom scores were not as dramatic as in NHAe 47-4 (score 2.8 - 4.1), Yolo Wonder (score - 3.4-5) and California Wonder (score - 3.1- 4.2). 
Table 1: Disease incidence on inoculated okra, pepper and tomato cultivars for the first two weeks after inoculation (WAI) with Cucumber mosaic virus under screenhouse and field conditions in Minna, Nigeria during the 2014 cropping season

\begin{tabular}{|c|c|c|c|c|}
\hline \multirow[b]{3}{*}{ Crop Cultivar } & \multicolumn{2}{|c|}{ Disease incidence $(\%)$} & & \multirow[b]{2}{*}{ Field } \\
\hline & \multicolumn{2}{|c|}{ Screenhouse } & \multirow{3}{*}{$1 \mathrm{WAI}$} & \\
\hline & $1 \mathrm{WAI}$ & $2 \mathrm{WAI}$ & & $2 \mathrm{WAI}$ \\
\hline \multicolumn{4}{|l|}{ Okra } & \\
\hline Clemson Spineless & 283 & 90.8 & 28.3 & 91.3 \\
\hline Ex-Bassawa-2 & 10.0 & 19.2 & 16.7 & 22.0 \\
\hline NHAe $47-4$ & 37.5 & 95.8 & 33.3 & 96.1 \\
\hline LSD0.05 & 5.7 & 5.4 & 8.2 & 3.5 \\
\hline $\mathrm{P}$-value & $*$ & $*$ & $*$ & $*$ \\
\hline \multicolumn{5}{|l|}{ Pepper } \\
\hline California Wonder & 44.2 & 96.3 & 50.3 & 98.3 \\
\hline Cayenne & 20.0 & 30.8 & 28.3 & 31.3 \\
\hline Yolo Wonder & 82.5 & 99.2 & 100.0 & 100.0 \\
\hline LSD0.05 & 6.8 & 1.5 & 3.3 & 1.0 \\
\hline $\mathrm{P}$-value & $*$ & $*$ & $*$ & $*$ \\
\hline \multicolumn{5}{|l|}{ Tomato } \\
\hline Roma Savanna & 0 & 16.7 & 0 & 18.1 \\
\hline Tropimech & 25.0 & 59.2 & 18.3 & 56.7 \\
\hline $\mathrm{UC} 82 \mathrm{~B}$ & 30.8 & 83.3 & 30.6 & 81.7 \\
\hline LSD 0.05 & 4.2 & 0.1 & 3.3 & 0.1 \\
\hline P-value & $*$ & $*$ & $*$ & $*$ \\
\hline
\end{tabular}

*Significant at $p=0.05$

Table 2: Disease severity on inoculated okra, pepper and tomato cultivars from 2 to 6 weeks after inoculation (WAI) with Cucumber mosaic virus under screenhouse and field conditions in Minna, Nigeria during the 2014 cropping season

\begin{tabular}{|c|c|c|c|c|c|c|}
\hline \multirow[b]{3}{*}{ Crop Cultivar } & \multicolumn{3}{|c|}{ Disease severity } & \multirow[b]{3}{*}{$2 \mathrm{WAI}$} & \multirow[b]{2}{*}{ Field } & \multirow[b]{3}{*}{$6 \mathrm{WAI}$} \\
\hline & \multirow[b]{2}{*}{$2 \mathrm{WAI}$} & \multicolumn{2}{|c|}{ Screenhouse } & & & \\
\hline & & $4 \mathrm{WAI}$ & $6 \mathrm{WAI}$ & & $4 \mathrm{WAI}$ & \\
\hline \multicolumn{7}{|l|}{ Okra } \\
\hline Clemson Spineless & 2.5 & 3.8 & 3.9 & 2.4 & 3.2 & 3.8 \\
\hline Ex-Bassawa-2 & 1.1 & 1.5 & 1.8 & 1.2 & 1.6 & 1.9 \\
\hline NHAe 47-4 & 2.9 & 3.7 & 4.1 & 2.8 & 3.6 & 4.0 \\
\hline LSD0.05 & 0.2 & 0.1 & 0.2 & 0.5 & 0.2 & 0.2 \\
\hline $\mathrm{P}$-value & $*$ & $*$ & $*$ & $*$ & $*$ & $*$ \\
\hline \multicolumn{7}{|l|}{ Pepper } \\
\hline California Wonder & 3.1 & 3.7 & 4.1 & 3.4 & 3.8 & 4.2 \\
\hline Cayenne & 1.7 & 2.7 & 2.9 & 1.5 & 2.2 & 2.6 \\
\hline Yolo Wonder & 3.4 & 3.8 & 4.2 & 4.2 & 5.0 & 5.0 \\
\hline LSD0.05 & 0.1 & 0.1 & 0.2 & 0.1 & 0.1 & 0.1 \\
\hline $\mathrm{P}$-value & $*$ & $*$ & $*$ & $*$ & $*$ & $*$ \\
\hline \multicolumn{7}{|l|}{ Tomato } \\
\hline Roma Savanna & 1.1 & 1.4 & 1.6 & 1.2 & 1.5 & 1.7 \\
\hline Tropimech & 1.7 & 2.4 & 3.0 & 1.6 & 2.3 & 2.9 \\
\hline UC82B & 2.2 & 2.9 & 3.4 & 1.8 & 2.5 & 3.1 \\
\hline LSD0.05 & 0.2 & 0.1 & 0.1 & 0.1 & 0.2 & 0.2 \\
\hline P-value & $*$ & $*$ & $*$ & $*$ & $*$ & $*$ \\
\hline
\end{tabular}

*Significant at $p=0.05$

Effect of cucumber mosaic virus disease on plant height

Uninoculated plants of all the evaluated cultivars exhibited normal and rapid growth contrary to those infected with CMV. The virus restricted plant height at varying levels among the crop cultivars (Table 3). For the screenhouse trial, uninoculated plants were significantly taller than the CMV infected plants except for Ex-Bassawa-2, Cayenne and Roma Savanna. However, in the field trial, uninoculated plants of all the cultivars were significantly taller than their infected counterparts. Among the three vegetables, height reduction was markedly highest in Yolo
Wonder in both screenhouse $(65.8 \%)$ and field $(100 \%)$ trials. It was also observed in the field study that the inoculated plants of Yolo Wonder died as a result of CMV infection. Among the okra cultivars, height reduction was mildest in the infected plants of ExBassawa-2 in both field $(1.5 \%)$ and screenhouse $(1.6 \%)$ evaluations. Conversely, while the CMV infected plants of NHAe47-4 exhibited the highest height reduction in the screenhouse study $(40.6 \%)$, field data indicated that plant height was severely impaired in the infected plants of Clemson Spineless (38.6 \%). Among the pepper cultivars, the CMV inoculated plants of Cayenne exhibited the lowest height reduction 
in both screenhouse $(6.5 \%)$ and field $(0.8 \%)$ trials. Similarly, the CMV infected plants of Roma Savanna showed the lowest height reduction $(3.4 \%)$ while height reduction was most conspicuous in the infected plants of UC82B (45\%).

\section{Effect of cucumber mosaic virus disease on leaf area}

The healthy plants produced broad leaves with normal shape while the leaves of CMV inoculated plants were narrow and twisted. The effect of CMV on leaf area of the evaluated vegetables is shown in Table 4 . The difference in leaf area between healthy and infected plants was not significant in ExBassawa-2 and Roma Savanna in both screenhouse and field trials. A similar phenomenon was encountered in Cayenne under screenhouse study. Conversely, healthy plants of the remaining cultivars produced significantly broader leaves than their infected counterparts. Overall, leaf area reduction was most conspicuous in infected plants of Yolo Wonder $(100 \%)$. Reduction in leaf area was less than $1 \%$ in infected plants of ExBassawa-2 under screenhouse $(0.8 \%)$ and field $(0.7 \%)$ conditions, as well as in Cayenne under field trial $(0.8 \%)$. Low reduction in leaf area was also observed in Roma Savanna under screenhouse $(7.6 \%)$ and field $(8.7 \%)$ conditions.

\section{Effect of cucumber mosaic virus disease on fruit length}

Infection by CMV reduced fruit length of the CMV infected plants while the healthy plants produced appreciably long fruits with normal shape. The data on fruit length from healthy and CMV inoculated plants are presented in
Table 5. In Ex-Bassawa-2, Cayenne and Roma Savanna, there was no significant difference in fruit length between healthy and CMV infected plants for both screenhouse and field study, as well as in Clemson Spineless under screenhouse trial. In contrast, healthy plants of the remaining cultivars produced significantly longer fruits than the infected plants. Generally, reduction in fruit length was less than $5 \%$ in Ex-Bassawa-2 under screenhouse $(3.6 \%)$ and field trials $(3.2 \%)$. Reduction in fruit length of Cayenne and Roma Savanna was 3.4 and $2.6 \%$, respectively under screenhouse study. Among the evaluated vegetables, high reduction in fruit length was found in NHAe47-4 (56.4 and 60.3\%) and Yolo Wonder (53.8 and $100 \%)$ under screenhouse and field trials.

\section{Effect of cucumber mosaic virus disease on fruit diameter}

The trend in fruit diameter was somewhat similar to that reported for fruit length. Fruits of the CMV infected plants were mostly smallsized, narrow and curled, contrary to the big fruits with normal shape obtained from the healthy plants. Under screenhouse and field conditions, fruits of the healthy plants were significantly wider than infected plants except in Ex-Bassawa - 2, Cayenne and Roma Savanna (Table 6). Generally, Yolo Wonder suffered the highest reduction in fruit diameter under screenhouse $(51.1 \%)$ and field $(100 \%)$ trials. Among the okra, pepper, and tomato cultivars, reduction in fruit diameter was mildest in Ex-Bassawa-2 (1.2 \%), Cayenne (8.3\%), and Roma Savanna. (3.1\%), respectively.

Table 3: Plant height from inoculated okra, pepper and tomato cultivars and uninoculated (healthy) with Cucumber mosaic virus under screenhouse and field conditions in Minna, Nigeria during the 2014 cropping season

\begin{tabular}{|c|c|c|c|c|c|c|c|c|c|c|}
\hline \multirow[b]{3}{*}{ Crop Cultivar } & \multirow[b]{3}{*}{ Healthy } & \multicolumn{7}{|c|}{ Plant height $(\mathrm{cm})$} & \multirow[b]{3}{*}{$\mathrm{P}$-value } & \multirow[b]{3}{*}{$\begin{array}{l}\text { Reduction } \\
(\%)\end{array}$} \\
\hline & & \multicolumn{3}{|c|}{ Screenhouse } & & & \multicolumn{2}{|r|}{ Field } & & \\
\hline & & Infected & LSD & $\mathrm{P}$-value & $\begin{array}{l}\text { Reduction } \\
(\%)\end{array}$ & Healthy & Infected & LSD & & \\
\hline \multicolumn{11}{|l|}{ Okra } \\
\hline Clemson Spineless & 47.4 & 35.5 & 2.4 & $*$ & 25.1 & 58.3 & 35.8 & 2.2 & $*$ & 38.6 \\
\hline Ex-Bassawa-2 & 36.8 & 36.2 & 1.2 & NS & 1.6 & 40.3 & 39.7 & 0.3 & $*$ & 1.5 \\
\hline NHAe 47-4 & 62.0 & 36.8 & 3.8 & $*$ & 40.6 & 72.1 & 45.3 & 3.4 & $*$ & 37.2 \\
\hline \multicolumn{11}{|l|}{ Pepper } \\
\hline California Wonder & 31.2 & 17.5 & 3.8 & $*$ & 43.9 & 35.1 & 19.7 & 1.9 & $*$ & 43.9 \\
\hline Cayenne & 35.5 & 33.2 & 3.2 & NS & 6.5 & 39.9 & 39.6 & 0.1 & $*$ & 0.8 \\
\hline Yolo Wonder & 28.1 & 9.6 & 4.6 & $*$ & 65.8 & 30.9 & 0 & 4.0 & $*$ & 100.0 \\
\hline \multicolumn{11}{|l|}{ Tomato } \\
\hline Roma Savanna & 50.3 & 48.6 & 2.8 & NS & 3.4 & 60.1 & 56.0 & 5.7 & NS & 6.8 \\
\hline Tropimech & 59.7 & 40.7 & 2.7 & $*$ & 31.8 & 67.0 & 52.5 & 6.3 & $*$ & 21.6 \\
\hline UC82B & 54.7 & 30.1 & 1.8 & $*$ & 45.0 & 52.1 & 34.6 & 6.2 & $*$ & 33.6 \\
\hline
\end{tabular}

*Significant at $p=0.05 ; \mathrm{NS}=$ Not Significant 
Salaudeen, M.T., Oluwatosin, O. and Gana, A.S.

33

Table 4: Leaf area from inoculated okra, pepper and tomato cultivars and uninoculated (healthy) with Cucumber mosaic virus under screenhouse and field conditions in Minna, Nigeria during the 2014 cropping season

\begin{tabular}{|c|c|c|c|c|c|c|c|c|c|c|}
\hline \multirow[b]{3}{*}{ Crop Cultivar } & \multirow[b]{3}{*}{ Healthy } & \multicolumn{9}{|c|}{ Leaf area $(\mathrm{cm} 2)$} \\
\hline & & \multicolumn{4}{|c|}{ Screenhouse } & \multicolumn{3}{|c|}{ Field } & \multirow[b]{2}{*}{ P-value } & \multirow[b]{2}{*}{$\begin{array}{l}\text { Reduction } \\
(\%)\end{array}$} \\
\hline & & Infected & LSD & P-value & $\begin{array}{l}\text { Reduction } \\
\%)\end{array}$ & Healthy & Infected & LSD & & \\
\hline \multicolumn{11}{|l|}{ Okra } \\
\hline Clemson Spineless & 106.9 & 74.1 & 14.2 & $*$ & 30.7 & 461.8 & 249.3 & 37.4 & $*$ & 46.0 \\
\hline Ex-Bassawa-2 & 103.6 & 102.8 & 7.2 & $\mathrm{NS}$ & 0.8 & 268.6 & 266.8 & 7.1 & NS & 0.7 \\
\hline NHAe 47-4 & 127.9 & 63.2 & 15.5 & $*$ & 50.6 & 498.9 & 248.0 & 38.0 & $*$ & 50.3 \\
\hline California Wonder & 32.1 & 14.5 & 4.5 & $*$ & 54.8 & 26.7 & 3.2 & 4.3 & $*$ & 88.0 \\
\hline Cayenne & 36.9 & 32.6 & 8.6 & NS & 11.7 & 39.0 & 38.7 & 0.1 & $*$ & 0.8 \\
\hline Yolo Wonder & 36.9 & 16.8 & 7.0 & $*$ & 54.5 & 26.7 & 0.0 & 0.6 & $*$ & 100.0 \\
\hline \multicolumn{11}{|l|}{ Tomato } \\
\hline Roma Savanna & 57.9 & 53.5 & 8.1 & NS & 7.6 & 43.8 & 40.0 & 5.0 & NS & 8.7 \\
\hline Tropimech & 50.8 & 38.6 & 6.8 & $*$ & 24.0 & 46.7 & 36.7 & 7.3 & $*$ & 21.4 \\
\hline UC82B & 45.8 & 25.5 & 6.2 & $*$ & 44.3 & 40.2 & 24.2 & 3.0 & $*$ & 39.8 \\
\hline
\end{tabular}

*Significant at $p=0.05 ; \mathrm{NS}=$ Not Significant

Table 5: Fruit length from inoculated okra, pepper and tomato cultivars and uninoculated (healthy) with Cucumber mosaic virus under screenhouse and field conditions in Minna, Nigeria during the 2014 cropping season

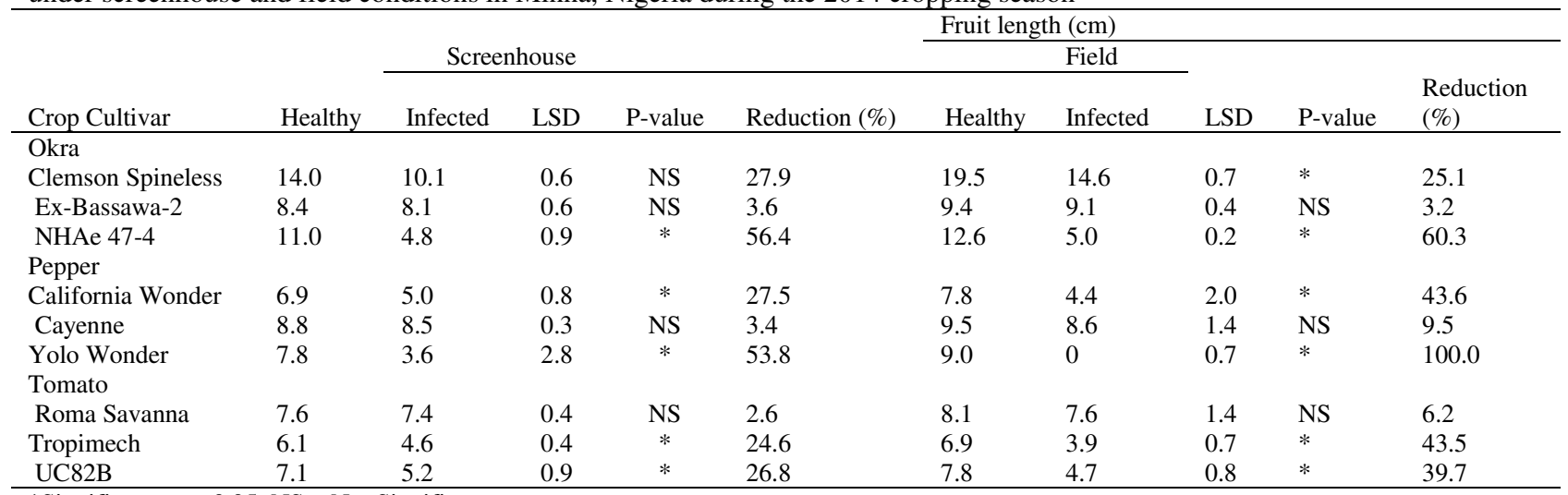

*Significant at $p=0.05 ; \mathrm{NS}=$ Not Significant

Table 6: Fruit diameter from inoculated okra, pepper and tomato cultivars and uninoculated (healthy) with Cucumber mosaic virus under screenhouse and field conditions in Minna, Nigeria during the 2014 cropping season

\begin{tabular}{|c|c|c|c|c|c|c|c|c|c|c|}
\hline \multirow[b]{3}{*}{ Crop Cultivar } & \multirow[b]{3}{*}{ Healthy } & \multirow[b]{3}{*}{ Infected } & \multirow{2}{*}{\multicolumn{2}{|c|}{ Screenhouse }} & & \multicolumn{2}{|c|}{ Fruit diameter $(\mathrm{cm})$} & \multirow{2}{*}{\multicolumn{2}{|c|}{ Field }} & \multirow[b]{3}{*}{$\begin{array}{l}\text { Reduction } \\
(\%)\end{array}$} \\
\hline & & & & & & & & & & \\
\hline & & & LSD & P-value & $\begin{array}{l}\text { Reduction } \\
(\%)\end{array}$ & Healthy & Infected & LSD & P-value & \\
\hline \multicolumn{11}{|l|}{ Okra } \\
\hline Clemson Spineless & 6.4 & 4.2 & 0.6 & $*$ & 34.4 & 6.7 & 5.3 & 0.6 & $*$ & 20.9 \\
\hline Ex-Bassawa-2 & 6.9 & 6.7 & 0.8 & NS & 2.9 & $8 . \mathrm{a}$ & 8.3 & 0.5 & NS & 1.2 \\
\hline NHAe 47-4 & 7.9 & 3.9 & 0.8 & $*$ & 50.6 & 9.2 & 5.8 & 1.5 & $*$ & 37.0 \\
\hline \multicolumn{11}{|l|}{ Pepper } \\
\hline California Wonder & 7.7 & 6.4 & 0.7 & $*$ & 16.9 & 9.1 & 6.0 & 2.3 & $*$ & 34.1 \\
\hline Cayenne & 2.9 & 2.5 & 0.5 & NS & 13.8 & 3.6 & 3.3 & 0.5 & NS & 8.3 \\
\hline Yolo Wonder & 9.0 & 4.4 & 3.2 & $*$ & 51.1 & 11.3 & 0 & 0.9 & $*$ & 100.0 \\
\hline \multicolumn{11}{|l|}{ Tomato } \\
\hline Roma Savanna & 9.8 & 9.5 & 0.5 & NS & 3.1 & 10.8 & 9.9 & 2.4 & NS & 8.3 \\
\hline Tropimech & 9.2 & 7.2 & 0.8 & $*$ & 21.7 & 9.3 & 6.7 & 1.0 & $*$ & 28.0 \\
\hline UC82B & 11.4 & 7.8 & 1.5 & $*$ & 31.6 & 12.8 & 8.7 & 3.0 & $*$ & 32.0 \\
\hline
\end{tabular}

*Significant at $p=0.05 ; \mathrm{NS}=$ Not Significant 
Table 7: Fruit weight from inoculated okra, pepper, and tomato cultivars and uninoculated (healthy) with Cucumber mosaic virus under screenhouse and field conditions in Minna, Nigeria during the 2014 cropping season

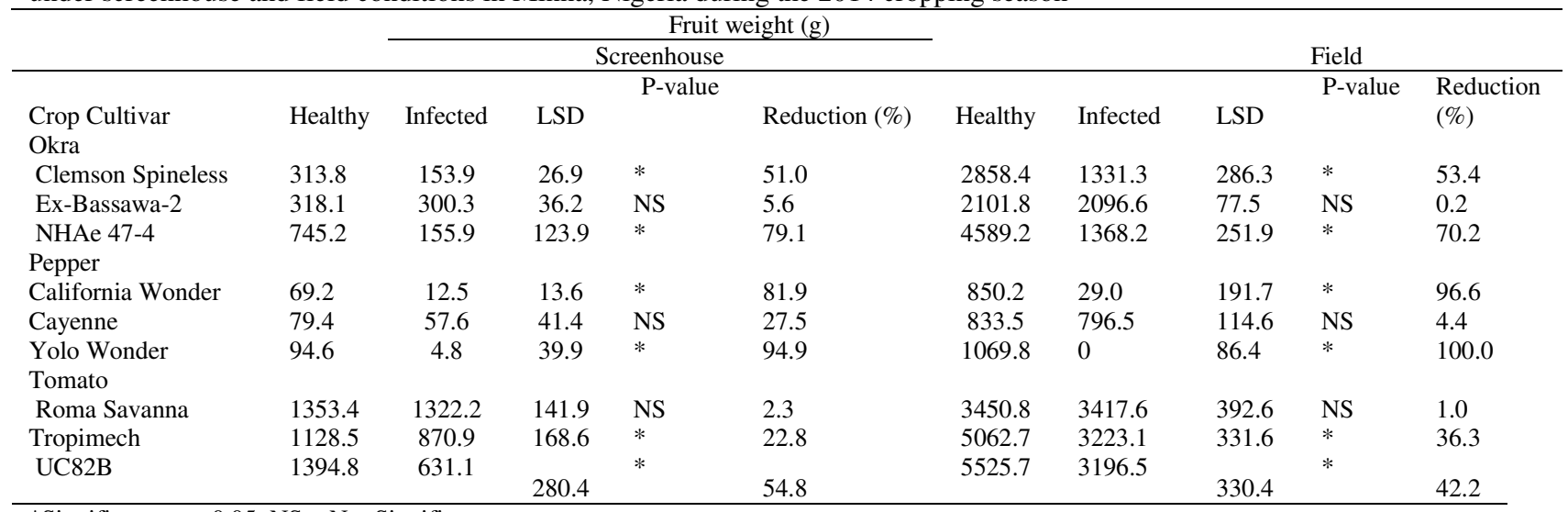

*Significant at $p=0.05 ; \mathrm{NS}=$ Not Significant

\section{Effect of cucumber mosaic virus disease on fruit weight}

Similar to the data on fruit diameter, the difference in fruit weight between healthy and infected plants was not significant in ExBassawa-2, Cayenne and Roma Savanna under screenhouse and field trials (Table 7). In the remaining cultivars, however, fruits of the healthy plants were significantly heavier than the CMV infected plants. Reduction in fruit weight was highest in Yolo Wonder both in the screenhouse $(94.9 \%)$ and field (100 \%) evaluation. Under screenhouse evaluation, the lowest reduction in fruit weight was observed in Roma Savanna $(2.3 \%)$ whereas Ex Bassawa-2 showed the mildest reduction in fruit weight $(0.2$ $\%$ ) under field conditions. The fruit weight reduction observed in Roma Savanna (1 \%) under field study was also negligible.

\section{DISCUSSION}

All the okra, pepper and tomato plants inoculated with CMV showed symptoms of infection. This is in agreement with the finding of Appiah et al. (2014) that CMV was pathogenic on several vegetable plants. The highest level of disease incidence in Yolo Wonder is an indication of its vulnerability to CMV. The high incidence of CMV observed in this study is in agreement with Arogundade et al. (2012) who encountered up to $87 \%$ incidence of CMV on pepper during a survey in Nigeria. Roma Savanna was the most tolerant because CMV inoculated plants were apparently symptomless till 14 days after inoculation. This observation is consistent with the findings of Gergerich and Dolja (2006) who stated that susceptibility or resistance to virus infection is determined by plant genetic makeup. The early appearance of symptoms in some cultivars corroborates the findings of Salaudeen and Aguguom (2014) when some cowpea accessions were infected with CMV. Furthermore, the symptoms observed on CMV inoculated plants were similar to those reported by Agrios (2005) where the older leaves of CMV-infected cucumber developed chlorosis and necrotic areas along the margins. Disease severity varied among the inoculated crop cultivars due to their different genetic make-up. The severity of infection increased over time in some cultivars, which is in agreement with the report of Aliyu et al. (2012) when some cowpeas were inoculated with B1CMV. Roma Savanna cultivar of tomato, which had the lowest level of CMV incidence and also elicited the mildest symptoms of infection, was probably due to the presence of CMV tolerance genes. It was observed that okra cv. Ex-Bassawa-2, pepper cv. Cayenne and tomato cv. Roma Savanna exhibited the lowest level of CMV incidence and severity in each crop group, NHAe 47-4, Yolo Wonder and UC82B cultivar of okra, pepper and tomato, respectively, exhibited the highest level of infection. This indicates variability in their tolerance to CMV infection. The observation that inoculated plants of Yolo Wonder suffered the highest level of infection (total crop loss) revealed that the genotype lacked CMV resistant genes. This finding corroborates that of Biswas et al. (2005) where the maximum incidence of disease (up to $80 \%$ ) and severity (up to 5) was observed in diseased chilli pepper. Jin et al. (2009) also reported that viral infection caused symptoms such as various forms of mosaic and distortions in plants with consequent reductions in crop growth and yield. The differences in morphological and yield data of the control (healthy) and inoculated plants are indications of pathogenicity of CMV on the tested vegetables. 
Salaudeen, M.T., Oluwatosin, O. and Gana, A.S.

The okra cv. Ex-Bassawa-2, pepper cv. Cayenne and tomato cv. Roma Savanna in which reductions in plant height, leaf area, fruit length, fruit diameter and fruit weight were lowest could be described as the best cultivars amongst others. Morphological and yield parameters of the CMV-infected plants were adversely affected by the virus and this resulted in the observed significant reductions. This is in agreement with the findings of Green (1992) who encountered severe losses in chilli plants infected with the virus. The better performance of uninoculated plants over the infected ones revealed that CMV could be devastating on the evaluated crops (okra, pepper and tomato) cultivars. Growth reduction in the viral infected plants was probably due to alterations of metabolic and physiological activities in diseased plants. This had been demonstrated in tomato plants infected with Potato virus $X$ (PVX) and Tomato mosaic virus (ToMV) (Balogun, 2003). The variation in fruit weight showed that as with the growth parameters, uninoculated (control) plants generally had higher biological yield values than viral infected plants. Fruit length and diameter had an obvious relationship with fruit size. The effects observed in inoculated okra, pepper and tomato cultivars could be attributed to the severity of CMV on fruit formation. In addition, the low level of growth and development of the susceptible plants agrees with Aeni (2007) who reported that the net assimilation of the virus-infected chilli plants was much lower than that of the healthy plants with substantial lower yield in diseased plants.

\section{CONCLUSION AND RECOMMENDATIONS}

This study revealed that plant height, leaf area, fruit length, fruit diameter and fruit weight were all reduced by Cucumber mosaic virus in okra, pepper and tomato. The Ex- Bassawa-2 cultivar of okra, Cayenne of pepper and Roma Savanna of tomato were the most tolerant to CMV. Clemson Spineless cultivar of okra and Tropimech of tomato were moderately tolerant. The UC82B cultivar of tomato was mildly tolerant while NHAe 47-4 of okra, Yolo Wonder and California Wonder of pepper were highly susceptible to CMV. It can be concluded, therefore, that the crop cultivars responded differently to infection, indicating that further breeding efforts should be intensified. This may eventually lead to the development of completely resistant (immune) cultivars that could also be introduced to vegetable growers in the nearest future. The okra cultivar Ex-Bassawa-2, pepper cultivar
Cayenne and tomato cultivar Roma Savanna could serve as sources of CMV-tolerant genes for breeding purposes. These could be crossed with susceptible genotypes for genetic improvement against the stresses imposed by CMV. Seed companies and Agricultural Development Programmes (ADPs) could multiply the seeds of these cultivars so that farmers would have easy access to highly productive seeds with disease tolerant genes. The pepper cultivar, Yolo Wonder infected with CMV suffered total crop loss. Hence, farmers should be careful to acquire seeds from reliable sources. Since CMV has been very successful in rapidly adapting to new hosts and environments, adoption of CMV resistant cultivars is very essential. Therefore, the three most tolerant cultivars (Ex- Bassawa2 cultivar of okra, Cayenne of pepper and Roma Savanna of tomato) are recommended to farmers in CMV prone areas.

\section{REFERENCES}

Abro A. and Sadaqat M. (2010). Poverty alleviation through diversifying towards high-value crops in Pakistan. Int. J. Business Manage. Econ. Res., 1 (1), 1-8

Aeni N.A. (2007). Study of the stability of the production of Chili curly yellow virus in endemic areas with optimization of plant nutrition. PhD Dissertation. Gajah Mada University of Yogyakarta, Indonesia

Agrios G.N. (2005). Plant Pathology (5thed.). Elsevier Academic Publishers. Amsterdam

Aliyu T.H. Balogun O.S. and Gbadebo F.M. (2012). Cowpea reaction to single and mixed viral infection with Blackeye cowpea mosaic virus. Agrosearch, 12, 174-183

Appiah A.S. Quartey E.K. Amoatey H.M. Nunekpeku W. Owusu-Ansah M. and Ofori S. (2014). Response of nine cultivars of pepper (Capsicum spp.) to infection by four viruses under natural field conditions in the coastal savanna zone of Ghana. Res. J. Appl. Sci. Eng. Techn., 7 (5), 903-907

Arif, M. and Hassan, S. (2002). Evaluation of resistance in soyabean germplasm to Soyabean mosaic Potyvirus under field conditions. Online J. Biol. Sci., 2, 601-604

Arogundade O. Olusegun S.B. and Kareem T.K. (2012). Occurrence and distribution of Pepper veinal mottle virus and Cucumber mosaic virus in pepper in Ibadan, Nigeria. J. Virol., 9, 79

Babalola D.A. Makinde Y.O. Omonona B.T. and Oyekanmi M.O. (2010). Determinants of postharvest losses in tomato production: a case study of Imeko - Afon local government area of Ogun State. J. Life Physical Sci., 3 (2), 14-18

Bakhru H.K. (2003). Foods that heal. the natural way to good health. Orient Paperbacks, Delhi, pp. $82-90$

Balogun O.S. (2003). Alterations in the accumulation of viral proteins and RNAs in tomato under mixed infection with Potato $\mathrm{X}$ 
Reactions of Okra, Pepper, and Tomato Cultivars to Cucumber Mosaic Virus Disease

Potexvirus and Tobacco mosaic Tobamovirus. Biokemistri, 13, 8-15

Biswas K.K. Pun K.B. Pant R.P. and Ashlawat Y.S. (2005). Mosaic disease in chilli (Capsicum annuum) cv. Kalimpong local in Darjeeling hills of West Bengal and its management. Indian Phytopathol., 58 (4), 456-461

FAO (Food and Agriculture Organization) 2016. Tomato production statistics. Available at http://faostat.fao.org/site/567/DesktopDefault.as px?PageID=567\#ancor. Accessed on May 1, 2017

Feldmann F. Alford D.V. and Furk C. (2009). Crop plant resistance to biotic and abiotic factors: Current Potential and Future Demands (Eds.). Proceedings of the 3rd International Symposium on Plant Protection and Plant Health in Europe held at the Julus Kühn-Institut, Berlin-Dahlem, Germany, 14-16 May 2009 jointly organised by the German Phytomedical Society (DPG) and the British Crop Production Council (BCPC) in co-operation with the Faculty of Agriculture and Horticulture (LGF), Humboldt University Berlin, and the Julius Kühn-Institut (JKI), Berlin, Germany

Gergerich R.C. and Dolja V.V. (2006). Introduction to plant viruses, the invisible foe. The Plant Health Instructor. DOI: 10.1094/PHI-I-20060414-01

Green S.K. (1992). Viruses in Asian pacific region. In: Proceedings of the Conference on Chilli pepper production in the tropics. pp. 98-129

Hartz T. and Cantwell M. (2008). Bell pepper production in California. University of California Cooperative Extension Specialists, Department of Plant Sciences, University of California, http://anrcatalog.ucdavis.edu Publication 7217

Idowu-Agida O.O. Nwaguma E.I. and Adeoye I.B. (2010). Cost implication of wet and dry season pepper production in Ibadan, Southwestern Nigeria. Agric. Biol. J. North America, 1 (4), 495-500.

Jin R. Pan J. Xie H. Zhou B. and Xia X. (2009). Separation and quantitative analysis of capsaicinoids in chili peppers by reversed-phase argentation LC. Chromatographia, 70, 5-6

Kumar P.L. (2009). Methods for the diagnosis of plant virus diseases: laboratory manual. International Institute of Tropical Agriculture (IITA), Ibadan, Nigeria. p. 90

Lin S-W. Chou Y.Y. Shieh H.C. Ebert A.W. Kumar S. Mavlyanova R. Rouamba A. Tenkouano A. Afari-Sefa V. and Gniffke, P.A. (2013). Pepper (Capsicum spp.) germplasm dissemination by AVRDC - The World Vegetable Center: an overview and introspection. Chronica Hortic., 53 (3), 21- 27
O'keefe D.C. Berryman D.I. Coutts B.A. and Jones R.A.C. (2007). Lack of seed coat contamination with Cucumber mosaic virus in lupin permits reliable, large-scale detection of seed transmission in seed samples. Plant Dis., 91, 504-508

Palukaitis P. and Garcia-Arenal F. (2003). Cucumoviruses. Adv. Virus Res., 62, 241-323

Rehima M. (2006). Analysis of red pepper marketing: The case of Alaba and Siltie in SNNPRS of Ethiopia. An M. Sc. Thesis submitted to the Department of Agricultural Economics, School of Graduate studies Haramaya University, pp 53-75

Rice R.P. Rice L.W. and Tindall H.D. (1987). Fruit and Vegetable Production in Africa. U.K. Macmillan Publishers, pp 371

Saifullah M. and Rabbani M.G. (2009). Evaluation and characterization of okra (Abelmoschus esculentus L. Moench.) genotypes. SAARC J. Agric., 7, 92-99

Salaudeen M.T. (2016). Growth and yield responses of some cowpea accessions to Cucumber mosaic virus infection. Arch. Agron. Soil Sci., 62, $289-$ 298

Salaudeen M.T. and Aguguom A. (2014). Identification of some cowpea accessions tolerant to Cowpea mild mottle virus. Int. J. Sci. Nature, 5, 261-267

Sarra S. (2005). Novel insights in the transmission of Rice yellow mottle virus in irrigated rice. Ph.D. Thesis. Wageningen University, Wageningen, The Netherlands

SAS (Statistical Analysis System) (2008). Statistical Analysis System SAS/STAT User's guide, ver. 9.2. SAS, Institute Inc., Cary NC

Taiwo M.A. (2001). Viruses infecting legumes in Nigeria: case history. In Plant virology in subSaharan Africa (Hughes, J dA and Odu, B.O eds.). Proceedings of a conference organized by the International Institute of Tropical Agriculture (IITA), Ibadan, $4-8$ June, 2001. Pp $365-380$.

Walker S.S. (2012).Okra gumbo and rice: The News Courier.

(http://portal.unesco.org/en/ev.phpURL_ID=238 77\&URL_DO=DO_TOPIC\&URL_SECTION= 201.html). Accessed on May 15, 2016 